\title{
LC-MS characterization of valsartan degradation products and comparison with LC-PDA
}

\author{
Sumaia Araújo Pires ${ }^{1}$, Letícia Martins Mota ${ }^{1}$, Jerusa Simone Garcia ${ }^{1}$, Phellipe Honorio Amaral ${ }^{2}$, \\ Eduardo César Meurer², Marcos Nogueira Eberlin², Marcello Garcia Trevisan ${ }^{1, *}$
}

${ }^{1}$ Laboratory of Pharmaceutical Analysis and Characterization, LACFar, Institute of Chemistry, Federal University of Alfenas, Alfenas, MG, Brazil, ${ }^{2}$ Thomson Laboratory of Mass Spectrometry, Institute of Chemistry, UNICAMP, Campinas, SP, Brazil

\begin{abstract}
Valsartan was submitted to forced degradation under acid hydrolysis condition as prescribed by the ICH. Degraded sample aliquots were separated via HPLC using a Hypersil ODS (C18) column (250 x $4.6 \mathrm{~mm}$ i.d., $5 \mu \mathrm{m}$ ). Either photodiode array (PDA) detection or mass spectrometry (MS) full scan monitoring of HPLC runs were used. HPLC-PDA failed to indicate Valsartan degradation under forced acid degradation, showing an insignificant peak area variation and that Valsartan apparently remained pure. HPLC-MS using electrospray ionization (ESI) and total ionic current (TIC) monitoring did not reveal any peak variation either, but inspection of the ESI mass spectra showed the appearance of $\mathrm{m} / \mathrm{z} 306$ and $\mathrm{m} / \mathrm{z} 352$ ions for the same retention time as that of Valsartan $(\mathrm{m} / \mathrm{z} 436)$. These ions were identified as being protonated molecules of two co-eluting degradation products formed by hydrolysis. These assignments were confirmed by ESI-MS/MS with direct infusion of the degraded samples. The results showed that the use of selective HPLC-MS is essential for monitoring Valsartan degradation. Efficient HPLC separation coupled to selective and structural diagnostic MS monitoring seems therefore mandatory for comprehensive drug degradation studies, particularly for new drugs and formulations, and for method development.
\end{abstract}

Uniterms: Valsartan. Stress testing. Degradation products. Stability-indicating. Acidic hydrolysis.

Valsartana (VAL) foi submetida à degradação forçada em meio ácido conforme procedimento descrito no ICH. Os produtos de degradação (PDs) foram monitorados ao longo do tempo de degradação pela técnica de Cromatografia Líquida (LC) utilizando uma coluna Hypersil ODS (C18) (250 x 4,6 mm d.i., $5 \mu \mathrm{m}$ ). A detecção foi feita com dois detectores: espectrofotométrico (PDA) e espectrometria de massas (MS) por corrente iônica total. Ambas as técnicas falharam na identificação dos PDs obtidos ao longo do monitoramento, mostrando insignificantes variações na área do pico e permanecendo com pureza de pico ao longo de toda a eluição. Somente depois da avaliação por íon extraído (XIC), foi possível observar o aumento do íon m/z 306 e m/z 352 exatamente no mesmo tempo de retenção do íon molecular (m/z 436). Estes resultados mostram um caso simples e didático em que somente o uso de um método seletivo de LC-MS pode ser utilizado para monitorar produtos de degradação. Neste trabalho, é apresentado um caso real em que a separação por LC deve ser acoplada a métodos seletivos obtidos por MS, especialmente no estudo de PDs para novos fármacos, formulações e no desenvolvimento de métodos.

Unitermos: Valsartana. Teste de estresse. Produtos de degradação. Indicativo de estabilidade. Hidrólise ácida.

*Correspondence: M. G. Trevisan. Laboratório de Análise e Caracterização de Fármacos - LACFar. Instituto de Química. Universidade Federal de Alfenas. 37130-000 - Alfenas - MG, Brasil. E-mail: trevisan@unifal-mg.edu.br 


\section{INTRODUCTION}

The identification of drug degradation products plays a crucial role in drug discovery and development (Alsante et al., 2003). Understanding drug degradation pathways affords information that is critical for drug safety and potency assessment, since very fast degradation and harmful degradation products may deactivate active molecules. The parent ICH stability testing guideline (ICH, 2003) and the Brazilian Health Surveillance Agency (ANVISA) (Brasil, 2013) require that drugs be subjected to a series of stress degradation studies, followed by proper characterization of the degradation products (DP).

Degradation studies via stress testing simulate the most likely environments that the drug may be subjected to from production to storage. These stress tests are important for inference of the degradation routes of pharmaceutical compounds and inform molecule stability across different stress conditions. The ICH guidelines (ICH, 2003) were conceived for the characterization of the inherent stability of a particular product, determination of possible DP, validation of the ability of analytical methods to evaluate the chemical stability of products and finally the quantification of the total and individual impurities present in formulations.

DP are normally associated with storage, but may also be formed during formulation dosage and/or processing under the influence of temperature, humidity, and light (Liu et al., 2011a). HPLC-PDA and HPLCUV are the primary stability-indicating methods used to monitor impurities/DP during stress testing and storage (Alsante et al., 2003). Although these techniques seem efficient for a variety of degradation studies (Thomas et al., 2012; Sharma et al., 2011; Bansal et al., 2008), they may fail to detect products lacking a chromophore group (Bansal et al., 2008) or with co-eluting sets of degradation products which may even co-elute with the parent drug and lead to false stability results.

HPLC-UV and HPLC-PAD are two largely used stability-indicating methods, but Liquid Chromatography Coupled to Mass Spectrometry (LC-MS) has become the gold standard technique in drug degradation monitoring due to its high DP sensitivity and selectivity as a result of the detailed structural information it provides (Zhang and Pramanik, 2010; Jocic et al., 2009; Bhardwaj, Singh, 2008; Liu et al., 2011b; Pan et al., 2011). At present, direct MS analysis approaches using soft ionization methods applied to drug pills have been reported and may also be suitable for some drugs (Amaral et al., 2011).

Valsartan (VAL) is a potent and highly selective oral drug largely used for the treatment of hypertension due to its effect as an active antagonist at the angiotensin II AT1-receptor (Krishanaiah et al., 2010) and because its solid-state characterization and compatibility have been established (Julio et al., 2013). In the present study, we report on false Valsartan stability results observed in a degradation study under acid stress condition using HPLC-PDA and the actual instability obtained by HPLCMS monitoring.

\section{MATERIAL AND METHODS}

\section{Samples and reagents}

Valsartan (VAL) was supplied by Dr. Reddys, India (batch AFEH002828) and used without further purification. MS grade Acetonitrile (ACN) from SigmaAldrich (São Paulo, Brazil), analytical grade acetic acid from Mallinckrodt Baker and hydrochloric acid $(\mathrm{HCl})$ were purchased from Merck (Darmstadt, Germany). Water was purified using a Millipore Direct-Q 3UV water purification system with pump (Millipore, Molsheim, France). A VAL stock solution of $1 \mathrm{mg} \cdot \mathrm{mL}^{-1}$ was prepared in acetonitrile.

\section{Acid stress condition}

Studies of VAL degradation by acidic hydrolysis were carried out in $1 \mathrm{M} \mathrm{HCl}$. For that, ca. $10 \mathrm{mg}$ VAL were weighed and quantitatively transferred to a $50-\mathrm{mL}$ two-neck round bottom flask and stirred with a magnetic bar with $50 \mathrm{~mL}$ of $1 \mathrm{M} \mathrm{HCl}$. The acidic mixture was kept in the dark and under reflux at $358 \mathrm{~K}$ for $3 \mathrm{~h}$. Samples were taken at 30-min intervals, neutralized and diluted with ammonium acetate buffer to $17 \mu \mathrm{g} \cdot \mathrm{mL}^{-1}$ prior to HPLC analysis.

\section{High Performance Liquid Chromatography (HPLC)}

HPLC separations were performed using a Hypersil ODS (C18) column $(250 \times 4.6 \mathrm{~mm}$ i.d., $5 \mu \mathrm{m})$ at room temperature in both HPLC-PDA and HPLC-MS apparatuses. Isocratic elution was carried out at $1 \mathrm{~mL} \cdot \mathrm{min}^{-1}$ with a mobile phase containing acetonitrile: water $(45: 55 \mathrm{v} / \mathrm{v}, 1.0 \%$ formic acid). The injection volume was $20 \mu \mathrm{L}$ in both cases. The HPLC-PDA system was made up of an on-line degasser (DGU-20S5), a liquid chromatography apparatus (LC20AT), a communication bus module (CBM-20A), an auto sampler (SIL-20A), a column oven (CTO-10ASVP), a photodiode array (PDA) detector (SPD-M20A) with scan range of 190-800 $\mathrm{nm}$ and LC Solutions software version 1.21 SP1 (Shimadzu, Kyoto, Japan). 
The HPLC-MS system was made up of an Alliance ${ }^{\circledR}$ HPLC separation module (Waters 2695) coupled to an electrospray (ESI) source and a QTrap 2000 mass spectrometer (Applied Biosystems/ABSciex). The ESI source temperature was $623 \mathrm{~K}$ and the transfer voltage was $4500 \mathrm{~V}$. The ESI was operated in positive ion mode, viz. $\operatorname{ESI}(+)$.

\section{ESI (+)- MS/MS analysis}

To study the fragmentation of $[\mathrm{VAL}+\mathrm{H}]^{+}$, a Q-TOF mass spectrometer (Micromass, Manchester, U.K.) was used for ESI(+)MS/MS analysis. Spectra were collected in the $\mathrm{m} / \mathrm{z}$ range from 50 to 500 . A formic acid aqueous solution was added to the sample mixture up to a total volume of $1,000 \mu \mathrm{L}$ and a final concentration of $0.1 \%$ $(\mathrm{v} / \mathrm{v})$. Direct infusion was performed at a flow rate of $10 \mu \mathrm{L} \mathrm{min}^{-1}$ via a syringe pump (Harvard Apparatus). High purity nitrogen at $1.5 \mathrm{~L} \mathrm{~min}^{-1}$ was used as a nebulizer as well as an auxiliary gas. The capillary and cone voltages were set at $3.0 \mathrm{kV}$ and $35 \mathrm{~V}$, respectively. Both the curved desolvation line (CDL) and heat block temperatures were maintained at $373 \mathrm{~K}$. Collision-induced dissociation (CID) of the selected precursor ion was carried out with argon as the collision gas at a pressure optimized to produce extensive fragmentation of the ion under investigation.

\section{RESULTS AND DISCUSSION}

\section{Degradation product monitoring}

Forced acid degradation of VAL was monitored by HPLC-PDA. Figure 1 shows the representative HPLC-PDA chromatograms of VAL samples under acid stress condition taken at 30-min intervals.

The retention time of VAL was $10.7 \mathrm{~min}$, which was confirmed by measurement of the drug standard

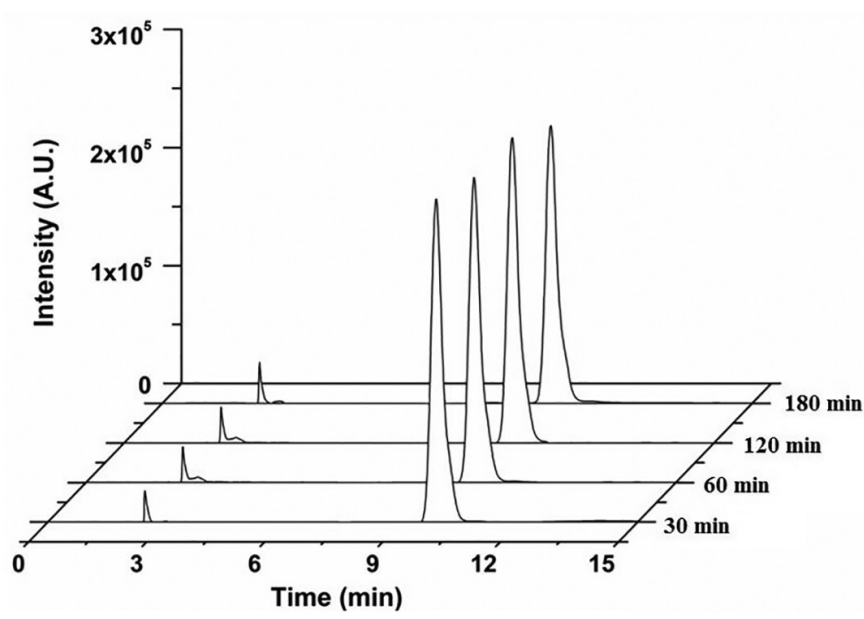

FIGURE 1 - HPLC-PDA chromatogram for forced acid degradation of VAL in $1 \mathrm{M} \mathrm{HCl}$ under different stress conditions.

solution. No extra peak indicative of degradation was detected during exposure to $1 \mathrm{M} \mathrm{HCl}$. Chromatographic data were also evaluated by asymmetric factor, theoretical plates and purity plot to identify the possible co-elution of degradation products. As shown in Figure 2, the VAL purity peak matches that of the VAL standard, showing no degradation over time. These results would induce the conclusion of high stability of VAL under exposure to 1 $\mathrm{M} \mathrm{HCl}$ up to $180 \mathrm{~min}$. However, the asymmetric factor and theoretical plates varied slightly over time under acid stress condition, as shown in Table 1, indicating a possible co-elution of degradation products.

To confirm the HPLC-PDA results, the same samples were also analyzed by HPLC-MS. Figure 3 shows HPLC chromatograms obtained using $\mathrm{ESI}(+)$ and total ion current (TIC) monitoring, which sums up the intensity of all ions across the selected $\mathrm{m} / \mathrm{z}$ range. Note that HPLCMS with TIC monitoring indicated no degradation either, likewise the HPLC-PDA results. A significance $t$-test was performed to compare the peak areas of the VAL standard
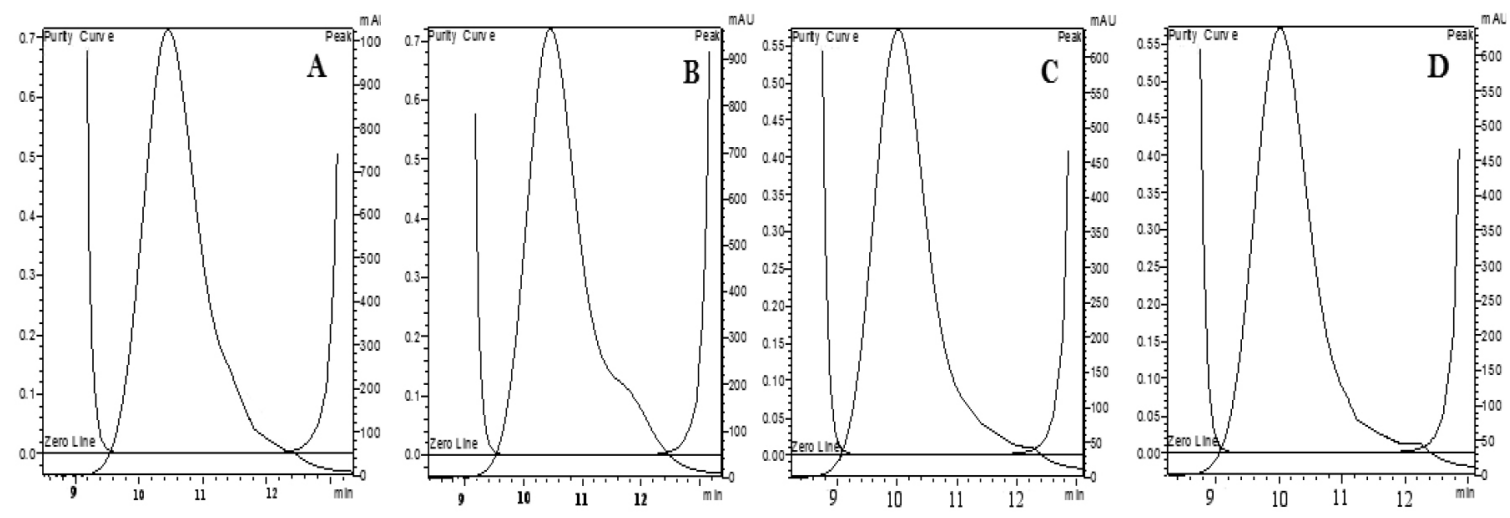

FIGURE 2 - Peak purity plot for forced acid degradation of VAL in $1 \mathrm{M}$ at $30 \mathrm{~min}$ (A), $60 \mathrm{~min}$ (B), $120 \mathrm{~min}$ (C) and $180 \mathrm{~min}$ (D). 
TABLE I - Asymmetry factor and theoretical plates of VAL at different times under acid stress condition

\begin{tabular}{lccccc}
\hline Time/min & 0 & 30 & 60 & 120 & 180 \\
\hline$A_{s}^{\mathrm{a}}$ & 1.3 & 1.4 & 1.2 & 1.5 & 1.8 \\
$N^{b}$ & 1410 & 1385 & 1210 & 1180 & 1071 \\
\hline
\end{tabular}

${ }^{\mathrm{a}}$ Asymmetry factor; ${ }^{\mathrm{b}}$ Theoretical plates

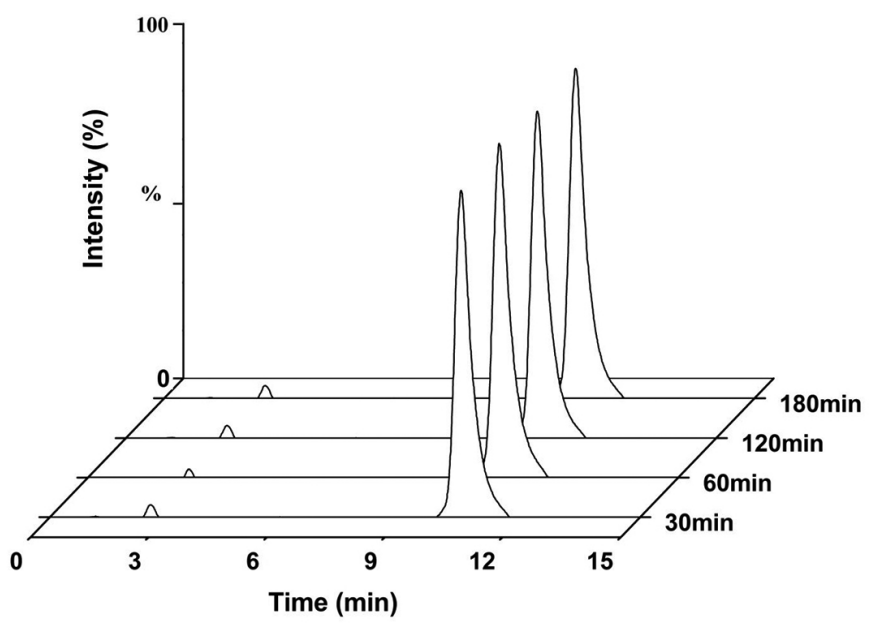

FIGURE 3 - HPLC-MS chromatograms using ESI(+) and TIC for the acid stress degraded samples of VAL.

$(n=3)$ and those in the chromatograms shown in Figure 1 and Figure 2. The degree of freedom is 10; therefore, the critical value is $t_{10}=2.23(P=0.05)$. The value obtained of $t=1.89$ is smaller than the critical value, thus, the variation in the VAL peak area is not significant when detected by PDA and MS.

Fortunately, however, the full ESI(+)-MS data was inspected, and as Figure 4 shows, at the VAL chromatographic peak at $10.7 \mathrm{~min}$, the raising of two major ions of $\mathrm{m} / \mathrm{z} 306$ and 352 was detected, together with the ions from the parent drug, that is, $\mathrm{m} / \mathrm{z} 436$ for $[\mathrm{M}+\mathrm{H}]^{+}$and $\mathrm{m} / \mathrm{z} 458$ for $[\mathrm{M}+\mathrm{Na}]^{+}$.

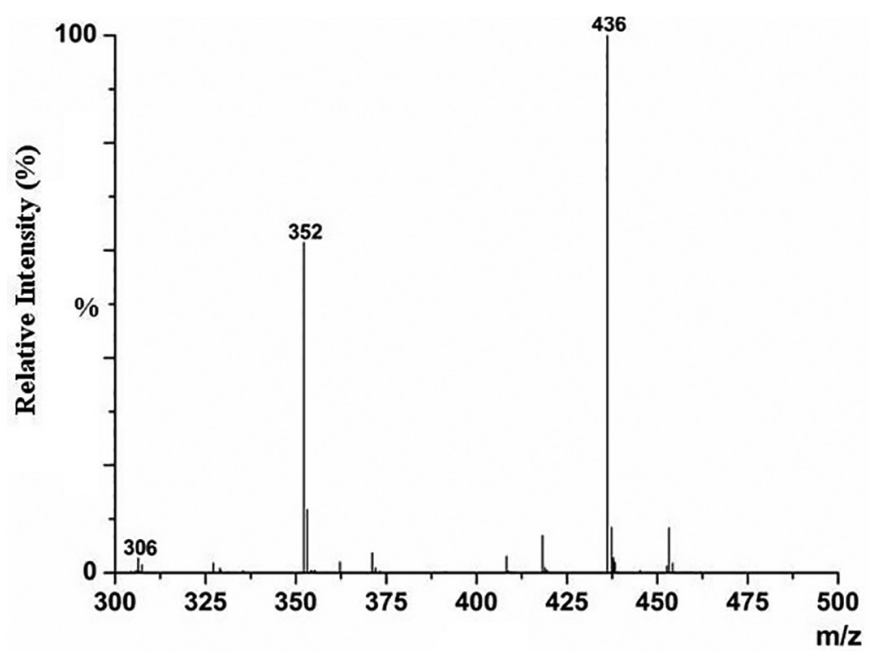

FIGURE 4 - Typical ESI(+) full mass spectrum for the VAL peak at $\mathrm{RT}=10.7 \mathrm{~min}$.

The ESI(+)-MS data unequivocally indicates that VAL indeed degraded to co-eluting products. The ions of $\mathrm{m} / \mathrm{z} 306$ and $\mathrm{m} / \mathrm{z} 352$, as well as that of VAL $(\mathrm{m} / \mathrm{z} 436)$, were therefore recorded in the extracted ion chromatograms (XIC) (Figure 5). The XIC for the other minor ions observed in Figure 4 were also recorded and monitored as a function of the degradation time, but their profiles did not match those of the DP and were attributed to either VAL ion gas phase fragments or impurities.

Note the continuous increase in the DP relative abundance as a function of the exposure time with a corresponding and proportional decrease in the VAL concentration. Therefore, the selective HPLC-MS data provided actual evidence of extensive degradation of VAL under acid stress condition, whereas HPLC-PAD incorrectly indicated full stability. Figure 6 compares HPLC-MS monitoring via TIC and XIC of VAL degradation under acid stress condition. The ions of $\mathrm{m} / \mathrm{z}$ 306 and $\mathrm{m} / \mathrm{z} 352$ were thus attributed to the arising of VAL
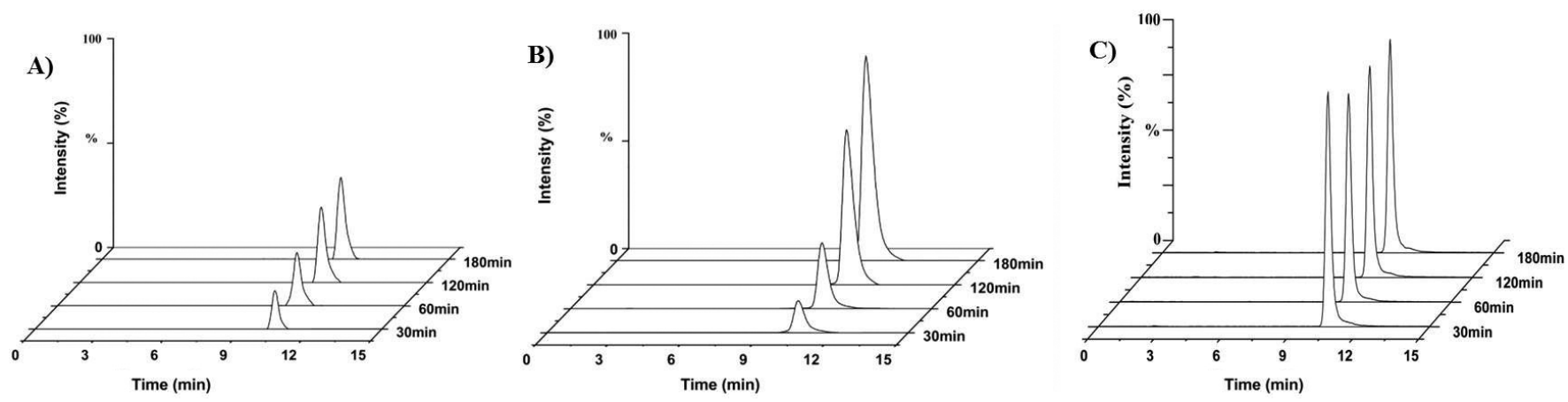

FIGURE 5 - HPLC-MS chromatograms using XIC monitoring for VAL degradation products: m/z 352 (A), m/z 306 (B) and $[\mathrm{VAL}+\mathrm{H}]^{+} \mathrm{m} / \mathrm{z} 436(\mathrm{C})$ in $1 \mathrm{M} \mathrm{HCl}$ for different exposure times. 


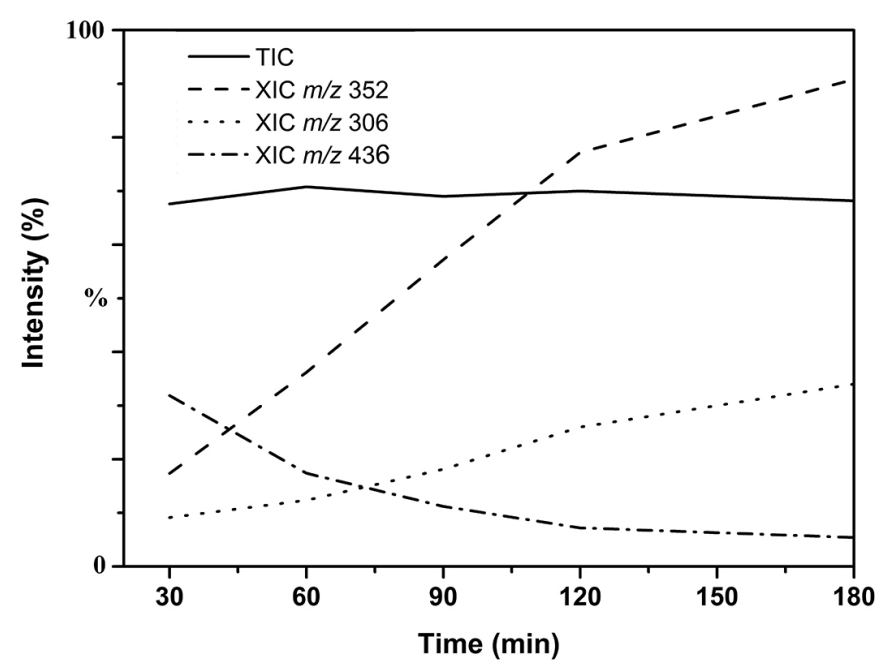

FIGURE 6 - VAL TIC and XIC HPLC-MS monitoring under acid stress degradation.<smiles></smiles><smiles>CC(C)C(NCc1ccc(-c2ccccc2-c2nnn[nH]2)cc1)C(=O)O</smiles>

Degradation Product (351 Da)

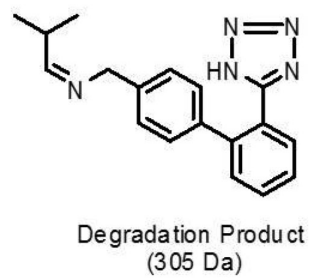

FIGURE 7 - VAL Degradation products as indicated by HPLC-MS monitoring.

DP protonated molecules by acid hydrolysis and Figure 7 shows the proposed product structures.

\section{ESI-MS/MS}

Interestingly, the MS study of the fragmentation pattern of gaseous drugs in protonated, deprotonated and ionized forms has been found to match or provide insights on their degradation mechanisms and products (Amaral et al., 2011). The fragmentation patterns of gaseous molecules reveal the weaker molecule bonds; hence, some of the fragment ions may eventually match degradation products, particularly when the behavior of a protonated molecule is compared to that expected under acid stress condition. Figure 8 shows the ESI (+)-MS/ $\mathrm{MS}$ of $[\mathrm{VAL}+\mathrm{H}]^{+}$of $\mathrm{m} / \mathrm{z} 436$, as well as of the protonated molecules of its two major products of $\mathrm{m} / \mathrm{z} 352$ and $\mathrm{m} / \mathrm{z}$
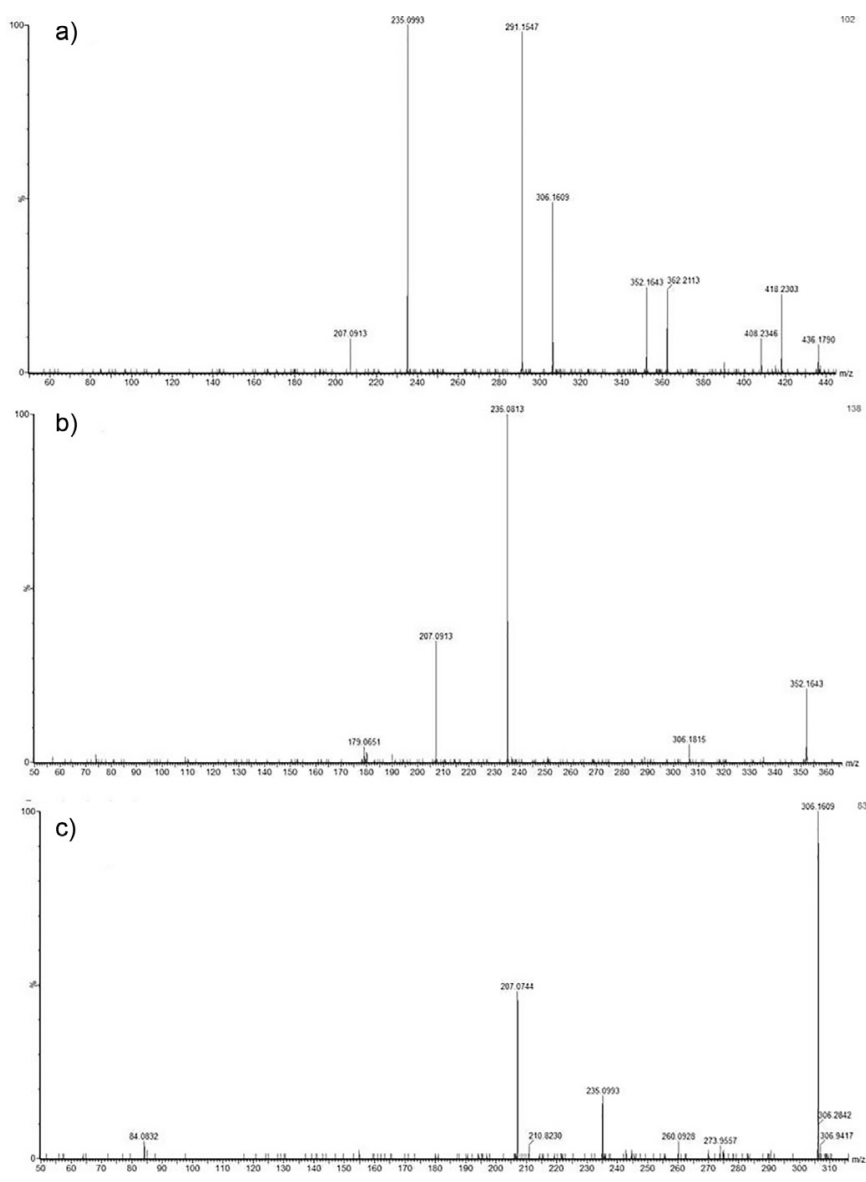

FIGURE 8 - ESI(+)-MSMS for the ions of a) $\mathrm{m} / \mathrm{z} 436$, b) 352 and c) 306 obtained via direct infusion of VAL samples after 180 min of exposure to acid stress condition.

306. Note that the fragments of $[\mathrm{VAL}+\mathrm{H}]^{+}$include the protonated molecules of $\mathrm{m} / \mathrm{z} 352$ and 306 of the detected DP (Scheme 1) (Mehta, Shah, Singh, 2010). The ESI (+)-MS/MS data for VAL and its DP may therefore include products that are likely to form under longer acid degradation.

\section{CONCLUSION}

HPLC-MS monitoring has shown that VAL degradation products under acid stress condition co-elute with the parent drug, resulting in misleading stability results when monitoring is performed through a less selective detection method such as HPLC-PAD. The high structural selectivity of HPLC-MS seems therefore required for comprehensive and effective studies of VAL degradation products and their formulations. Actually, HPLC-MS seems to be essential for drug degradation studies, particularly for new drugs and formulations, as well as for method development. Drug stability methods 
developed through HPLC-UV or HPLC-PAD and so far exclusively monitored by either of these methods should therefore be co-validated by HPLC-MS in search for potential co-eluting degradation products.

\section{ACKNOWLEDGMENTS}

The authors would like to thank Fundação de Amparo a Pesquisa do Estado de Minas Gerais (FAPEMIG) and Capes/CNPq (PROCAD) for financial support.

\section{REFERENCES}

ALSANTE, K.M.; MARTIN, L.; BAERTSCHI, S.W. A stress testing benchmarking study. Pharm. Technol., v.27, n.2, p.60-72, 2003.

AMARAL, P.H.; FERNANDES, R.; EBERLIN, M.N.; HOEHR, N.F. Direct monitoring of drug degradation by easy ambient sonic-spray ionization mass spectrometry: the case of enalapril. J. Mass Spectrom., v.46, n.12, p.1269-1273, 2011.

BANSAL, G.; SINGH, M.; JINDAL, K.C.; SINGH, S. LC-UV-PDA and LC-MS studies to characterize degradation products of glimepiride. J. Pharm. Biomed. Anal., v.48, n.3, p.788-795, 2008.

BHARDWAJ, S.P.; SINGH, S. Study of forced degradation behavior of enalapril maleate by LC and LC-MS and development of a validated stability-indicating assay method. J. Pharm. Biomed. Anal., v.46, n.1, p.113-120, 2008.

BRASIL. Ministério da Saúde. Agência Nacional de Vigilância Sanitária. RDC no. 58, de 20 de dezembro de 2013. Estabelece parâmetros para a notificação, identificação e qualificação de produtos de degradação em medicamentos com substâncias ativas sintéticas e semissintéticas, classificados como novos, genéricos e similares, e dá outras providências. Diário Oficial da União. Brasília, 23 dez. 2013. Seção 1, p.127-128.

INTERNATIONAL CONFERENCE ON HARMONIZATION

(ICH). Stability testing of new substances and products, in: proceedings of the international conference on harmonization. Geneva: IFPMA, 2003. Available at: Q1A (R2) (2003) Guidance for Industry. International Conference on harmonization, IFMPA, Geneva. Available at: <http://www.ich.org/products/guidelines.html $>$. Accessed on: 03 Jun. 2014.
JOCIC, B.; ZECEVIV, M.; ZIVANOVIC, L.; PROTIC, A.; JADRANIN, M.; VAJS, V. Study of forced degradation behavior of eletriptan hydrobromide by LC and LC-MS and development of stability-indicating method. J. Pharm. Biomed. Anal., v.50, n.4, p.622-629, 2009.

JULIO, T.A.; ZAMARA, I.F.; GARCIA, J.S.; TREVISAN, M.G. Compatibility and stability of valsartan in a solid pharmaceutical formulation. Braz. J. Pharm. Sci., v.49, n.4, p.645-651, 2013.

KRISHNAIAH, C.; REDDY, A.R.; KUMAR, R.; MUKKANTI, K. Stability-indicating UPLC method for determination of valsartan and their degradation products in active pharmaceutical ingredient and pharmaceutical dosage forms. J. Pharm. Biomed. Anal., v.53, n.3, p.483-489, 2010.

LIU, Z.Y.; ZHANG, H.H.; CHEN, X.J.; ZHOU, X.N.; WAN, L.R.; SUN, Z.L. Structural elucidation of degradation products of olaquindox under stressed conditions by accurate mass measurements using electrospray ionization hybrid ion trap/time-of-flight mass spectrometry. Int. J. Mass Spectrom., v.303, n.2-3, p.90-96, 2011a.

LIU, Z.Y.; ZHOU, X.N.; ZHANG, H.H.; WAN, L.R.; SUN, Z.L. An integrated method for degradation products detection and characterization using hybrid ion trap/ time-of-flight mass spectrometry and data processing techniques: application to study of the degradation products of danofloxacin under stressed conditions. Anal. Bioanal. Chem., v.399, n.7, p.2475-2486, 2011 b.

MEHTA, S.; SHAH, R.P.; SINGH, S. Strategy for identification and characterization of small quantities of drug degradation products using LC and LC-MS: application to valsartan, a model drug. Drug Test. Anal., v.2, n.2, p.82-90, 2010.

PAN, C.K.; GUAN, J.; LIN, M. A multidisciplinary approach to identify a degradation product in a pharmaceutical dosage form. J. Pharm. Biom. Anal., v.54, n.4, p.855-859, 2011.

SHARMA, M.; JAWA, P.R.; GILL, R.S.; BANSAL, G. Citalopram hydrobromide: degradation product characterization and a validated stability-indicating LC-UV method. J. Braz. Chem. Soc., v.22, n.5, p.836-848, 2011. 
THOMAS, S.; SHANDILYA, S.; BHARTI, A.; AGARWAL, A. A stability indicating simultaneous dual wavelength UVHPLC method for the determination of potential impurities in fampridine active pharmaceutical ingredient. J. Pharm. Biomed. Anal., v.58, n.1, p.136-140, 2012.
ZHANG, L.K.; PRAMANIK, B.N. Characterization of major degradation products of an adenosine $\mathrm{A}(2 \mathrm{~A})$ receptor antagonist under stressed conditions by LC-MS and FT tandem MS analysis. J. Mass Spectrom., v.45, n.2, p.146$156,2010$.

Received for publication on $03^{\text {rd }}$ June 2014 Accepted for publication on $26^{\text {th }}$ September 2015 
